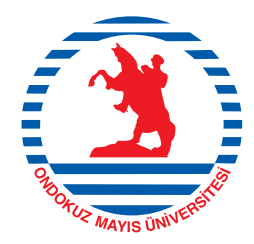

Anadolu Tarım Bilimleri Dergisi

Anadolu Journal of Agricultural Sciences

http://dergipark.gov.tr/omuanajas

\title{
Araştırma/Research
}

Anadolu Tarım Bilim. Derg./Anadolu J Agr Sci, 35 (2021) ISSN: 1308-8750 (Print) 1308-8769 (Online) doi: 10.7161/omuanajas.927060

\section{Honey marketing problems and honey consumption habits in Erzurum}

\author{
-Dilek Kabakcı ${ }^{a} *$, $\odot$ Ahmet Dodoloğlu ${ }^{2}$ \\ ${ }^{1}$ Department of Animal Production and Technologies, Faculty of Applied Sciences, Muş Alparslan University, Muş, \\ Turkey \\ ${ }^{2}$ Department of Animal Science, Faculty Agricultural, Atatürk University,Erzurum, Turkey \\ *Sorumlu yazar/corresponding author: dilek_kabakci@ hotmail.com \\ Geliş/Received 24/04/2021 Kabul/Accepted 04/08/2021

\begin{abstract}
In this study a survey was made for determining honey consumption habits and honey marketing problems between1-31 March 2010. In the consumers based research data were collected from (105 consumers) criterias when buying honey, different kinds and health benefits of honey in Erzurum. According the assesments of results; it was found that $46.66 \%$ of consumers consumed $5 \mathrm{~kg}$ of honey per capita per annum and taken into consideration using honey every day. It was determined that the product quality and floral source of honey were more important than price, brand name, region, flavour and colour for consumers. Most of the consumers $(60.95 \%)$ prefered cenrifugal honey in this study. According to the survey findings, the brand did not have an important effect on consumers' honey consumption and purchasing habits. This result revealed that there was a negative situation about production and marketing of honey in Erzurum.
\end{abstract}

\section{Erzurum piyasasında bal pazarlama sorunları ve bal tüketim alışkanlıkları}

\section{ÖZET}

Erzurum yöresinde, bal tüketim alışkanlıklarını ve bal pazarlama sorunlarını belirlemek amacıyla, 1 31 Mart 2010 tarihleri arasında, bir anket çalışması yapılmıştır. Ankete katılan 105 tüketiciye ait veriler, bal satın alırken dikkat ettikleri hususlardan, bal tercihlerinden ve sağlık açısından balın faydalarından elde edilmiştir. Değerlendirme sonuçlarına göre; tüketicilerin \%46.66'sının yılda $5 \mathrm{~kg}$ bal tükettiği ve günlük beslenmelerinde mutlaka bal kullandıkları belirlenmiştir. Tüketicilerin bal alırken fiyat, marka, bolge, tat, koku ve renkten daha çok kalitesine ve üretildiği kaynağa önem verdikleri belirlenmiştir. Ayrıca, tüketicilerin çoğunun $(\% 60.95)$ bal tüketiminde süzme bal tercih ettikleri de tespit edilmiştir. Tüketicilerin bal satın alma ve tüketim alışkanlıklarında markaya önem vermemeleri, markalı bal üretimi ve pazarlanması açısından olumsuz bir durumu ortaya çıkardığı

Keywords Beekeeping, Honey marketing problems, Honey consumption, Consumption Habits belirlenmiştir. 


\section{Introduction}

Beekeeping, using herbal resources, bee and family work force together and effectively, with products such as honey, pollen, royal jelly, propolis, bee venom, which human beings cannot give up for human food, health protection and treatment, as well as queen, swarm, pack bee It is the whole activity of producing living materials such as (Firatll et al., 2000). Honey, pollen, royal jelly, beeswax, propolis and bee venom obtained from honey bees are of great economic and ecological importance. In addition, it is very important for human nutrition and health and is used as a medicine in the treatment of many diseases (Kaftanoğlu et al., 1992; Kumova, 2001). Honey is the most produced main bee product in the world. However, beeswax, pollen, royal jelly, bee venom and propolis are also important beekeeping products (Firatlı and Gençer., 1994). Honey yield per colony reaches 40-64 kg, especially in some countries with developed beekeeping. According to the 2018 FAO data, average 114113 tonnes, is Turkey's third largest honey-producing countries in the world honey production. However, it ranks low in productivity with a yield level of 15-16 kg per colony. Turkey, despite the fact that the world's third-largest honey producer, honey exports is very low. urkey, Saudi Arabia, especially in Germany, France, the Netherlands, Cyprus, Kuwait, Italy, the honey exported to countries such as Spain. 95\% of pine honey is exported to EU countries (FAO, 2018). Turkey, climate, vegetation and has a very positive potential for apiculture as natural conditions such as topographic structure. The beekeeping sector has shown a great development in recent years. However, the increase in production per colony is far below the value required by natural conditions. Although the total bee hive existence, the ratio of modern hives and the density of colonies per unit area have continuously increased since the 1960s, the productivity did not increase at the same level. However, what is important in beekeeping is not the number of colonies, but the level of productivity (Firatl et al., 2000). Despite the increase in the number of bee colonies in Turkey every year, it has dropped honey yield per colony. When the data of previous years are examined, honey yield per colony is $15-16 \mathrm{~kg}$. This decrease is thought to be due to the increase in the number of colonies (FAO, 2008; Anonim 2019). Beekeeping in Erzurum is far below the potential required by the ecological wealth of the province. In order for the beekeeping in the region to reach the desired level, it is necessary to conduct research and guide beekeepers on issues such as the use of breeding and modern equipment, bee health, and reducing the loss of feeding and wintering. Apart from this, there is a need for scientific suggestions on preparing colonies for nectar flow, modern arrangement of apiaries, prevention of swarming, organization of beekeepers, raising awareness of consumers about bee products and marketing (Anonim 2004). In this study, in order to investigate honey marketing problems in Erzurum, a survey was conducted on consumers who visit different honey stores and the answers of the participants were recorded. Thus, it was aimed to determine the awareness level of the consumers by asking them questions about honey consumption, honey preference, and whether honey is consumed in sicness or not and suggest solutions on the Erzurum honey marketing problems.

Table. 1. Number of hives in the year 2009-2019 in Turkey, honey production and yield (Anonymous 2019). Çizelge. 1. 2009-2019 Yllları İtibariyle Türkiye'de Kovan Saylsı, Bal Üretimi ve Verimi (Anonim 2019).

\begin{tabular}{cccccc}
\hline Years & $\begin{array}{c}\text { Primitive } \\
\text { Hive (piece) }\end{array}$ & Modern Hive (piece) & Total Hives (piece) & $\begin{array}{c}\text { Honey Production } \\
\text { (tonne) }\end{array}$ & $\begin{array}{c}\text { Honey Yield } \\
\text { (kg/ colony) }\end{array}$ \\
\hline 2012 & 21307 & 6191232 & 6.348 .009 & 89162 & 14.04 \\
2013 & - & 6458083 & 6.274 .818 & 94694 & 15.10 \\
2014 & - & 6888907 & 7.082 .732 & 103525 & 14.6 \\
2015 & - & 7525652 & 7.748 .287 & 108128 & 14.00 \\
2016 & - & 7679482 & 7.900 .364 & 105727 & 13.38 \\
2017 & - & 7796666 & 7.991 .072 & 114471 & 14.32 \\
2018 & - & 7904502 & 8.108 .424 & 107920 & 13.30 \\
2019 & - & 7929368 & 8.128 .360 & 109330 & 13.45 \\
\hline
\end{tabular}

\section{Material and Method}

\subsection{Materials}

\subsection{Preparation of survey forms}

A questionnaire has been prepared in order to determine the honey marketing problems and consumer consumption habits in Erzurum. In the preparation of the questionnaire, the source related to the subject, the information and documents collected were evaluated, and experts and organizations were used. It was determined that the sample size was suffiicient. 


\subsection{Surveys on honey marketing and consumption habits have been prepared.}

\section{Method}

\subsection{Data Collection Method}

The research was carried out according to the full chance trial plan. Within the framework of this plan, the honey marketing businesses to be surveyed were determined. The questionnaire forms were filled byface to face interviews with the business owner and customers in the determined businesses. The enterprises surveyed have been visited 2-3 times at different times.

\subsubsection{Surveys}

The same questionnaire forms were used for every customer who came to honey businesses. The questionnaire forms are grouped under four main headings. The first part is about honey consumption habits and the issues to be considered when buying honey, the second part is about honey preferences, the third part is about the properties of real honey and the fourth part is about the benefits of honey in terms of health.

\subsubsection{Data Collection Application}

Between 1-31 March 2010, a survey was applied to customers who come to honey marketing businesses to buy honey.

\subsubsection{Data Evaluation}

Statistical analysis of the data was done in SPSS 13.0 statistical package program. A total of 105 customers, 44 female and 51 male, were surveyed. Proportional distribution was used to evaluate the data. In addition, the collected data were summarized in rxc dimensional tables and $\mathrm{X}^{2}$ (chi-square) method was used for the independence test related to them. In cases where the frequencies of the observed values are less than 5 , the following equation is used.

$$
\begin{aligned}
& \sum\left(\left|m_{i}-b_{i}\right|-0,5\right)^{2} \\
& \mathrm{X}^{2}=-\mathrm{b}_{\mathrm{i}}
\end{aligned}
$$

$\mathrm{m}_{\mathrm{i}}=$ observed

$b_{i}=$ expected frequencies (Yıldiz ve Bircan 1994).

One-Way Analysis of Variance (ANOVA / one way) was used in the analysis of the answers given to the questions asked between genders.

\section{Results and Discussion}

\subsection{Annual honey consumption}

The respondents were asked how much their annual honey consumption is and they were asked to make a selection for $5 \mathrm{~kg}, 10 \mathrm{~kg}, 15 \mathrm{~kg}$ and $20 \mathrm{~kg}$. According to the answers given, the annual honey consumption amount of men and women was determined. In the statistical analyzes regarding annual honey consumption, it was observed that there was no relationship between gender and honey consumption, while the rate of those consuming 5 $\mathrm{kg}$ was found to be higher and insignificant $(\mathrm{p}<0.05)$ (Table 2).

Table.2. Chi-square Table for Annual Honey Consumption Çizelge. 2. Ki-kare Testi(Ylllkk Bal Tüketimine İlişkin Ki-kare Tablosu

\begin{tabular}{cccc}
\hline Gender $\mathrm{x}$ & $\mathrm{Df}$ & $\mathrm{X}^{2}$ & $\begin{array}{c}\text { Importance } \\
\text { level }\end{array}$ \\
\cline { 2 - 4 } $\begin{array}{c}\text { Annual honey } \\
\text { consumption }\end{array}$ & 2 & 7.809 & $\mathrm{~ns}$ \\
\hline
\end{tabular}

$\mathrm{p}<0.05$; ns: Insignificant 
Table 3. Annual Honey Consumption Distribution by Gender

Çizelge.3. Cinsiyete Göre Yıllık Bal Tüketim Dă̆ılımı

\begin{tabular}{lccccc}
\hline & Woman & Man & Woman $(\%)$ & $\begin{array}{c}\text { Man } \\
(\%)\end{array}$ & $\begin{array}{c}\text { General } \\
(\%)\end{array}$ \\
\cline { 2 - 4 } \multicolumn{1}{c}{ Options } & $\mathrm{n}$ & $\mathrm{n}$ & & & \\
\hline $5 \mathrm{~kg}$ & 34 & 23 & 62.96 & 45.09 & 54.02 \\
\hline $10 \mathrm{~kg}$ & 13 & 10 & 24.07 & 19.60 & 21.90 \\
\hline $15 \mathrm{~kg}$ & 5 & 11 & 9.25 & 21.56 & 15.23 \\
\hline $20 \mathrm{~kg}$ & 2 & 7 & 3.70 & 13.72 & 8.57 \\
\hline
\end{tabular}

The highest annual honey consumption among women and men was obtained with $62.96 \%$ and $45.09 \%$, respectively, at $5 \mathrm{~kg}$. Most of the respondents (54.02\%) consume $5 \mathrm{~kg}$ of honey per year, followed by $21.90 \%$ to 10 $\mathrm{kg}$ and $15.23 \%$ to $15 \mathrm{~kg}$, respectively (Table 3 ). In the survey results obtained, most of the participants consumed honey. In terms of annual honey consumption among the male and female groups, it is observed that women have the habit of purchasing more honey. In the previous survey study, the majority of the participants reported that they consume 5-10 kg of honey annually (Roman et al., 2013; Marta et al., 2015; Sayll, 2013; Saner et al., 2011; Kumova ve Korkmaz 2000). Research results are consistent with our study. Baki 2017, reported the annual honey consumption per person as $1.55 \mathrm{~kg}$ in her study in the province of İzmir in 2017, and it was determined that it was incompatible with our study (Baki, 2017).

\subsection{Use of honey in daily nutrition}

In the questionnaire, the participants answered the question "Do you absolutely use honey in your daily diet" as "YES, NO or OCCASIONALLY". In the $\mathrm{X}^{2}$ test, the effect of gender on daily honey nutrition was found to be insignificant, while the rate of those who said yes was higher and significant $(p<0.05)$ compared to other answers. (Table 4).

Table 4. Chi-square Test Results for Daily Honey Nutrition Çizelge 4. Günlük Bal Beslenmesine Illişkin Ki-kare Test Sonucu

Chi-square Test

\begin{tabular}{ccccc}
\hline Gender $\mathrm{x}$ & Df & $\mathrm{X}^{2}$ & \multicolumn{2}{c}{ Importance level } \\
\cline { 2 - 5 } $\begin{array}{c}\text { Daily } \\
\text { Honey }\end{array}$ & 2 & 0.22 & \multicolumn{2}{c}{$\mathrm{ns}$} \\
Nutritio & & & & \\
\hline $\begin{array}{c}\text { Varyasyon } \\
\text { Kaynağ }\end{array}$ & Df & KO & F & $\begin{array}{c}\text { Importance } \\
\text { level }\end{array}$ \\
\hline $\begin{array}{c}\text { Daily } \\
\text { Honey }\end{array}$ & 1 & 27.21 & 40.13 & $*$ \\
Nutrition & & & & \\
\hline
\end{tabular}

Chi-square Test

\begin{tabular}{llcc}
\hline Gender $\mathrm{x}$ & Df & $\mathrm{X}^{2}$ & $\begin{array}{c}\text { Importance } \\
\text { level }\end{array}$ \\
$\begin{array}{c}\text { Daily } \\
\text { Honey }\end{array}$ & 2 & 0.22 & $\mathrm{~ns}$ \\
Nutrition & & & \\
\hline *: $\mathrm{p}<0.05 ;$ ns: Insignificant & &
\end{tabular}

Among the respondents, the rates of those who answered "YES" were 51.85\% and 50.98\% for men and women, respectively. While the rate of women who answered "NO"' to the same question was $5.56 \%, 7.84 \%$ of the men answered "NO". The rate of those who say "I use it occasionally" is $42.59 \%$ for women and $48.57 \%$ for men (Table 5). Roman et al., 2013 reported the rate of those consuming honey daily as $26.7 \%$. Sayll reported that $45.83 \%$ of the consumers in Tokat province consumed honey daily. It is parallel to our study. 
Table 5. Honey Usage Rate in Daily Nutrition

Çizelge5. Günlük Beslenmede Bal Kullanımı Oranı

\begin{tabular}{|c|c|c|c|c|c|}
\hline & Woman & Man & Woman (\%) & Man & General 1 \\
\hline Options & $\mathrm{n}$ & $\mathrm{n}$ & & & \\
\hline Yes & 28 & 26 & 51.85 & 50.98 & 51.42 \\
\hline No & 3 & 4 & 5.55 & 7.84 & 6.66 \\
\hline Occasionally & 23 & 21 & 42.59 & 41.17 & 41.90 \\
\hline
\end{tabular}

As a result of the survey study, it has been determined that women and men take care to use honey almost every day.

\subsection{Use of alternative food instead of honey}

In the questionnaire study, the answers to the question "Do you use alternative foods such as jam, marmalade etc. instead of honey" were recorded as "YES, NO or OCCASIONALLY'. According to the statistical analysis, the effect of gender was insignificant in the consumers' use of other products (jam, marmalade, etc.) instead of honey. (Table 6).

Table 6. Chi-square Test Results Regarding Use of Alternative Nutrients Instead of Honey Çizelge 6. Bal Yerine Alternatif Besin Kullanımına İlişkin Ki-kare Test Sonucu

\begin{tabular}{lccc}
\hline & \multicolumn{3}{c}{ Ki-Kare Testi } \\
\hline $\begin{array}{l}\text { Gender } \mathrm{x} \\
\begin{array}{l}\text { Alternative } \\
\text { food }\end{array}\end{array}$ & $\mathrm{Df}$ & $\mathrm{X}^{2}$ & $\begin{array}{c}\text { Importance } \\
\text { level }\end{array}$ \\
\cline { 2 - 4 } $\begin{array}{l}\text { instead of } \\
\text { honey }\end{array}$ & 2 & 4.81 & $\mathrm{~ns}$ \\
ns: Insignificant & & & \\
\hline
\end{tabular}

Among the participants, the answers of "YES, NO or OCCASIONALLY" were $42.59 \%, 18.51 \%$ and $38.88 \%$ for females, respectively, while these rates were $29.41 \%, 37.25 \%$ and $33.33 \%$ for males, respectively (Table7).

Table 7. Use of Alternative Nutrients Instead of Honey

Çizelge 7. Bal Yerine Alternatif Besin Kullanımı

\begin{tabular}{|c|c|c|c|c|c|}
\hline \multirow[b]{2}{*}{ Options } & Woman & Man & \multirow[t]{2}{*}{ woman (\%) } & \multirow{2}{*}{$\begin{array}{c}\text { Man } \\
(\%)\end{array}$} & \multirow[t]{2}{*}{ General (\%) } \\
\hline & $\mathrm{n}$ & $\mathrm{n}$ & & & \\
\hline Yes & 23 & 15 & 42.59 & 29.41 & 36.19 \\
\hline No & 10 & 19 & 18.51 & 37.25 & 27.61 \\
\hline Occasionally & 21 & 17 & 38.88 & 33.33 & 36.19 \\
\hline
\end{tabular}

According to the survey results, the rate of women using alternative food instead of honey was found to be higher than men. It has been observed that males prefer more honey, while females also consume alternative products instead of honey. In a study, the answer to the question "Do you use alternative products instead of honey?" was investigated. Accordingly, 55.5\% answered that I use jam instead of honey. It has been determined that the research is compatible with our study (Arvanitoyannisland Krystallis). Participants were asked what criteria they take into account when buying honey and whether color is important in the quality of honey. The criteria for purchasing honey were evaluated as quality, price, brand and region. The effect of color on honey quality was evaluated as "YES, NO or DON'T KNOW". In the statistical analysis of the survey results, while the effect of gender on the criteria taken into account when purchasing honey was found to be insignificant, it was revealed that the effect of quality on consumers was more important than other criteria $(\mathrm{p}<0.05)$ (Table 7$)$. 


\subsection{The criteria consumers pay attention to when purchasing honey}

According to the chi-square test, the effect of color on the quality of honey is important and its value is insignificant when evaluated in terms of gender.

Among the other criteria that most of the consumers participating in the survey pay attention to when purchasing honey, taste, smell, color and the relationship between the source from which it is produced and gender are insignificant, and the source from which the honey is produced is found important compared to the others $(\mathrm{p}<0.05)$ (Table 8).

Table 8 Chi-Square Test Results Regarding the Criteria Considered in Honey and the Effect of Color on Quality Çizelge 8. Balda Dikkat Edilen Kriterler ve Rengin Kaliteye Etkisine İlişkin Ki-kare test Sonucu

\begin{tabular}{cccc}
\hline \multicolumn{3}{c}{ Chi-Square Test } \\
\hline $\begin{array}{c}\text { Gender } x \\
\text { criteria to be } \\
\text { considered in } \\
\text { honey }\end{array}$ & Df & $\mathrm{X}^{2}$ & $\begin{array}{c}\text { Importance } \\
\text { level }\end{array}$ \\
\cline { 2 - 4 } & 3 & 8.14 & $\mathrm{~ns}$ \\
\hline $\begin{array}{c}\text { Gender } \mathrm{x} \\
\text { Color }\end{array}$ & 2 & 4.870 & $\mathrm{~ns}$ \\
\hline $\begin{array}{c}\text { Gender } \mathrm{x} \\
\text { Other criteria }\end{array}$ & 3 & 4.32 & $\mathrm{~ns}$ \\
\hline
\end{tabular}

*: $\mathrm{p}<0.05$; ns: Insignificant

It has been determined that the consumers pay attention to the quality of $76.19 \%$, the price of $7.16 \%$, the brand of $8.57 \%$ and the region of $7.61 \%$ when buying honey. Survey respondents, those who care about price and brand were recorded as $1.85 \%$ and $12.96 \%$ for women, $13.72 \%$, and $3.92 \%$ for men, respectively (Table 8 ).

Tablo 9. Distribution of Effective Criteria for Honey Purchase by Gender

Çizelge 9. Cinsiyete Göre Bal Satın Almada Etkili Kriterlere İlişkin Dağılım

\begin{tabular}{|c|c|c|c|c|c|}
\hline \multirow[b]{2}{*}{ Options } & Woman & Man & \multirow[t]{2}{*}{ Woman (\%) } & \multirow{2}{*}{$\begin{array}{c}\text { Man } \\
(\%)\end{array}$} & \multirow[t]{2}{*}{ General (\%) } \\
\hline & $\mathrm{n}$ & $\mathrm{n}$ & & & \\
\hline Quality & 43 & 37 & 79.62 & 72.54 & 76.19 \\
\hline Price & 1 & 7 & 1.85 & 13.72 & 7.61 \\
\hline Brand & 7 & 2 & 12.96 & 3.92 & 8.57 \\
\hline Region & 3 & 5 & 5.55 & 9.80 & 7.61 \\
\hline \multicolumn{6}{|c|}{$\begin{array}{l}\text { Does Color Affect the Quality of Honey? } \\
\text { Balın Kalitesine Rengin Etkisi Var mıdır? }\end{array}$} \\
\hline Yes & 41 & 34 & 75.92 & 66.66 & 71.42 \\
\hline $\mathrm{NO}$ & 3 & 10 & 5.55 & 19.60 & 12.38 \\
\hline I do not know & 10 & 7 & 18.51 & 13.72 & 16.19 \\
\hline
\end{tabular}

While $71.42 \%$ of the participants said "yes, it is important", $12.38 \%$ answered "no" whether the color has an effect on the quality of honey (Table 9). 
Table 10. Other Criteria Considered By Consumers When Buying Honey Çizelge 10. Tüketicilerin Bal Alırken Dikkat Ettikleri Diğer Kriterleri

\begin{tabular}{|c|c|c|c|c|c|}
\hline & Woman & Man & Woman (\%) & Man & General (\%) \\
\hline Options & $\mathrm{n}$ & $\mathrm{n}$ & & $(\%)$ & \\
\hline Taste & 15 & 15 & 27.77 & 29.41 & 28.57 \\
\hline Smell & 7 & 12 & 12.96 & 23.52 & 18.09 \\
\hline Color & 9 & 3 & 16.66 & 5.88 & 11.42 \\
\hline $\begin{array}{l}\text { Source from which i } \\
\text { produced }\end{array}$ & is & 21 & 42.59 & 41.17 & 41.90 \\
\hline
\end{tabular}

Other criteria that consumers pay attention to when buying honey are taste, odor, color and the source from which it is produced. While $41.90 \%$ of the participants buy honey, $28.57 \%$ prefer the source from which it is produced and the taste (Table 10). Although the preferences of women and men in terms of taste, smell and color while purchasing honey are not very high, it has been observed that they attach more importance to taste after the source from which honey is produced. According to the results of the survey study, it was observed that consumers pay attention to the quality and source of honey while buying honey, and the color is not important in the quality of honey. Sayll stated in her study in 2013 that taste, smell, color and the source from which it was produced were statistically insignificant when asked questions such as taste, smell, color, source of production in honey purchasing. Arvanitoyannis and Krystallis 2006 study, stated that consumers' smell, consistency, aroma, color, brand and label information are important. It has been determined that it is compatible with our research results.

\subsection{Consumers' ways of protecting honey}

Participants answered the question of "HOW DO YOU PROTECT YOUR HONEY" in the questionnaire as a cupboard, kitchen, glass jar or all of them. As a result of the chi-square test, it was observed that there was no relationship between gender and the way of preserving honey, while the rate of those who preferred glass jars was higher than those who said cupboard, kitchen or all (Table 11).

Table 11. Chi-square Test Results Regarding Honey Protection ways

Çizelge 11. Bal Koruma Şekillerine İlişkin Ki-kare Test Sonucu

\begin{tabular}{cccc}
\hline \multicolumn{4}{c}{ Chi-Square Test } \\
\hline $\begin{array}{c}\text { Gender } x \\
\begin{array}{c}\text { Honey } \\
\text { protection } \\
\text { style }\end{array}\end{array}$ & Df & $\mathrm{X}^{2}$ & $\begin{array}{c}\text { Importance } \\
\text { level }\end{array}$ \\
\hline & 3 & 1.473 & $\mathrm{~ns}$ \\
\hline
\end{tabular}

ns: Insignificant

$64.76 \%$ of the consumers stated that they prefer glass jars, $19.04 \%$ cupboards, kitchen and glass jars, $10.47 \%$ only the kitchen and $5.71 \%$ only the cupboard Table 3.10In the male and female groups, the highest honey preservation type was found to be glass jars, and the rate of those using cupboards, kitchens and glass jars was $22.22 \%$ for women and $15.68 \%$ for men.

Table 12. Honeys Preserved in Different Ways According to Gender

Çizelge 12.. Cinsiyete Göre Farklı Şekillerde Muhafaza Edilen Ballar

\begin{tabular}{|c|c|c|c|c|c|}
\hline \multirow[b]{2}{*}{ Options } & Woman & Man & \multirow[t]{2}{*}{ Woman (\%) } & \multirow{2}{*}{$\begin{array}{c}\text { Man } \\
(\%)\end{array}$} & \multirow[t]{2}{*}{ General (\%) } \\
\hline & $\mathrm{n}$ & $\mathrm{n}$ & & & \\
\hline Refrigerator & 2 & 4 & 3.70 & 7.84 & 5.71 \\
\hline Kitchen & 6 & 5 & 11.11 & 9.80 & 10.47 \\
\hline Glass Jars & 34 & 34 & 62.96 & 66.66 & 64.76 \\
\hline all of them & 12 & 8 & 22.22 & 15.68 & 19.04 \\
\hline
\end{tabular}


The results of the research show that consumers generally prefer glass jars for preserving honey. These preferences of the participants are thought to be in terms of hygiene, ease of use, long-term preservation or visuality.

\subsection{Consumers' thoughts about crystallizing honey and ways to remove crystallization}

Participants were asked about their thoughts about crystallizing honey and their preferred method of removing crystallization. Their thoughts about honey were evaluated as "fake honey", "good honey", "I can't say anything" and "it doesn't matter", and their way of removing crystallization was evaluated as heating, keeping it at $45{ }^{\circ} \mathrm{C}$, keeping it at room temperature and putting it in boiling water with its container. While the relationship between gender and thoughts about crystallizing honey was found to be insignificant according to the chi-square test; The relationship between gender and the methods to remove crystallization was found to be significant $(\mathrm{p}<0.05)$. (Table 12).

Table 13. Crystallized Honey and Crystallization Removal Analysis and Chi-square Test Result Çizelge 13. Kristalleşen Bal ve Kristalleşmenin Giderilmesine Illişkkin Ki-kare Test Sonucu

Chi-Square Test

\begin{tabular}{|c|c|c|c|}
\hline \multirow[t]{2}{*}{$\begin{array}{l}\text { Gender x Crystallizing } \\
\text { honey }\end{array}$} & g & $X^{2}$ & $\begin{array}{c}\text { Importance } \\
\text { level }\end{array}$ \\
\hline & 3 & 0.88 & $\mathrm{~ns}$ \\
\hline $\begin{array}{l}\text { Gender } \\
\text { Crystallization } \\
\text { removal }\end{array}$ & 3 & 8.33 & $*$ \\
\hline
\end{tabular}

$*: \mathrm{p}<0.05 ;$ ns: Insignificant

$40.74 \%$ of women and $43.13 \%$ of men think that crystallized honey is good honey, and the ratio of women and men who think that crystallized honey is fake honey is $33.33 \%$ and $25.49 \%$, respectively (Table 13 ).

Table 14. Participants' Opinions on Crystallized Honey and Their Preferences in Removing Crystallization Çizelge 14. Katılımcıların Kristalleşen Bal Hakkındaki Düşünceleri ve Kristalleşmeyi Gidermedeki Tercihleri

\begin{tabular}{|c|c|c|c|c|c|}
\hline \multirow[b]{2}{*}{ Options } & Woman & Man & \multirow[t]{2}{*}{ Woman (\%) } & \multirow{2}{*}{$\begin{array}{c}\text { Man } \\
(\%)\end{array}$} & \multirow{2}{*}{$\begin{array}{c}\text { General } \\
(\%)\end{array}$} \\
\hline & $\mathrm{n}$ & $\mathrm{n}$ & & & \\
\hline Fake honey & 18 & 13 & 33.33 & 25.49 & 29.52 \\
\hline Good honey & 22 & 22 & 40.74 & 43.13 & 41.90 \\
\hline I can't say anything & 10 & 11 & 18.51 & 21.56 & 20 \\
\hline It does not matter & 4 & 5 & 7.40 & 9.80 & 8.57 \\
\hline
\end{tabular}

Consumers' preferred ways to remove crystallization

Tüketicilerin kristalleşmeyi gidermede tercih ettikleri yollar

\begin{tabular}{lccccc}
\hline Heating & 5 & 14 & 9.25 & 27.45 & 18.09 \\
\hline Holding at $45{ }^{0} \mathrm{C}$ & 4 & 7 & 7.40 & 13.72 & 10.47 \\
\hline Holding at room temperature & 8 & 7 & 14.81 & 13.72 & 14.28 \\
\hline Holding in boiling water bowl & 37 & 23 & 68.51 & 45.09 & 57.14 \\
\hline
\end{tabular}

Considering that the response rates of the participants to good honey and fake honey are close to each other, it is understood that consumers have little information about crystallizing honey. When asked about the way consumers prefer to remove crystallized honey, only $7.40 \%$ of women and $13.72 \%$ of men preferred to keep it at $45^{\circ} \mathrm{C}$. On the other hand, it was determined that $68.51 \%$ of women and $45.09 \%$ of men chose to put the crystallized honey in boiling water with its container. According to the results of the survey, it is concluded that consumers who see crystallized honey as a defect should be made conscious. Considering the way the consumers follow in bringing the crystallized honey to its consistency, it is observed that they also have insufficient knowledge on this subject. 
3.7. Consumers' use of honey for therapeutic purposes in the disease

In the question of whether consumers use honey in the treatment of various diseases, the answers received were evaluated as "sometimes, never and always". In the statistical analyzes made, the chi-square test was applied to test the relationship between gender and the use of honey for therapeutic purposes and the test results were found to be insignificant. It was determined that the effect of gender was significant $(\mathrm{p}<0.05)$ in the answers regarding the use of honey for therapeutic purposes in diseases. (Table 15).

Table 15. Chi-square Test Results Regarding the Therapeutic Use of Honey in Diseases Çizelge 15. Hastalıklarda Balın Tedavi Amaçlı Kullanılması İle İlgili Ki-kare Test Sonucu

\begin{tabular}{lccc}
\hline Chi-Square Test & & & \\
\hline $\begin{array}{l}\text { Gender } x \text { Use of } \\
\text { honey in diseases }\end{array}$ & Df & $\mathrm{X}^{2}$ & $\begin{array}{c}\text { Importance } \\
\text { level }\end{array}$ \\
\cline { 2 - 4 } & 2 & 0.23 & $\mathrm{~ns}$ \\
\hline *: $\mathrm{p}<0.05$ & & &
\end{tabular}

$59.25 \%$ of women sometimes use honey for treatment when you get sick, 35.18\% of them always use it, and 5.55\% of them stated that they never use it. It was determined that most of the participants (58.09\%) used honey for treatment purposes (Table 3.14). Arvanitoyannis and Krystallis, 2006, in their research findings, reported that honey consumed for skin, anti-aging, anti-cancer, and health. Kumova and Korkmaz reported in 2000 studies that honey was used in diseases such as Pharyngitis, Ulcer, Gastritis, Common Cold, Angina, Diabetes, Asthma, Bronchitis, Cancer. The research results have been determined to be consistent with our findings.

3.8. What consumers think about real honey prices

One of the questions asked to the participants is their thoughts on real honey prices. Alternatively, they were asked to choose between "important, not important and depending on the situation." As a result of the test, the relationship between gender and consumers' opinions about real honey prices were found to be insignificant (Table 16).

Table 16. Chi-square Test Results for Real Honey Prices Çizelge 16. Gerçek Bal Fiyatları Ille Illgili Ki-kare Test Sonиси

\begin{tabular}{|c|c|c|c|}
\hline \multicolumn{4}{|c|}{ Chi-Square Test } \\
\hline Gender x Real honey prices & Df & $\mathrm{X}^{2}$ & Importance level \\
\hline & 1 & 2.98 & $\mathrm{~ns}$ \\
\hline
\end{tabular}

ns: Insignificant

Table 17. Distribution Status of Actual Honey Price by Gender Çizelge 17. Cinsiyete Göre Gerçek Bal Fiyatı İle İlgili Dă̆glım Durumu

\begin{tabular}{|c|c|c|c|c|c|}
\hline \multirow[b]{2}{*}{ Options } & Woman & Man & \multirow{2}{*}{$\begin{array}{c}\text { woman } \\
(\%)\end{array}$} & \multirow{2}{*}{$\begin{array}{c}\text { Man } \\
(\%)\end{array}$} & \multirow{2}{*}{$\begin{array}{c}\text { General } \\
(\%)\end{array}$} \\
\hline & $\mathrm{n}$ & $\mathrm{n}$ & & & \\
\hline Important & 15 & 18 & 27.77 & 35.29 & 31.42 \\
\hline unimportant & 19 & 20 & 35.18 & 39.21 & 37.14 \\
\hline It depends on the situtation & 20 & 13 & 37.03 & 25.49 & 31.42 \\
\hline
\end{tabular}

$35.18 \%$ of the women and $39.21 \%$ of the men answered the question of whether the honey you buy is real honey and its price is important for you. In terms of price, the rate of those who said that people are "important or depends on the situation" was recorded as $31.42 \%$ (Table 17). As a result of the survey, it is seen that while the price does not matter in the preferences of some of the consumers to consume quality honey, the price is important for some of them.

\subsection{Questions about real honey}

The respondents were asked whether the honey candied in the refrigerator, honey flowing intermittently and honey that does not freeze in cold weather are real, and the answers were recorded as "yes or no". According to the chisquare test, the effect of gender was found to be insignificant and the relationship between sex and intermittently flowing honey was found to be significant $(\mathrm{p}<0.05)$. On the other hand, the answers given to whether honey that does not freeze in cold weather is real or not was found to be significant between genders $(\mathrm{p}<0.05)$ (Table 3.17). 
Table 18. Chi-square Test Results Related to Real Honey

Çizelge 18.. Gerçek Bal İle İlgili Ki-kare Test Sonucu

\begin{tabular}{cccc}
\hline \multicolumn{3}{c}{ Chi-Square Test } \\
\hline $\begin{array}{c}\text { Gender x Candied honey } \\
\text { in the fridge }\end{array}$ & $\mathrm{Df}$ & $\mathrm{X}^{2}$ & $\begin{array}{c}\text { Importance } \\
\text { level }\end{array}$ \\
\cline { 2 - 4 } & 1 & 0.25 & $\mathrm{~ns}$ \\
\hline $\begin{array}{c}\text { Gender x Intermittent } \\
\text { flow of Honey }\end{array}$ & 1 & 4.93 & $*$ \\
\hline $\begin{array}{c}\text { Gender x Honey freezing } \\
\text { in cold weather }\end{array}$ & 1 & 1.31 & $\mathrm{~ns}$ \\
\hline$* \mathrm{p}<0.05 ;$ ns: Insignificant & & & \\
\hline
\end{tabular}

'If your honey is candied in the refrigerator, is it real honey? 'was asked to the respondents. The rate of women saying yes and no was equal (50\%), $54.90 \%$ for men and $47.61 \%$ for men. A great majority of the participants $(72.38 \%)$ think that honey flowing intermittently is fake (Table 18).

Table 19. Distribution Status Related to Real Honey Questions by Gender Çizelge 19. Cinsiyete Göre Gerçek Bal Soruları İle Illgili Dağılım Durumu

\begin{tabular}{|c|c|c|c|c|c|}
\hline \multirow[b]{2}{*}{ Options } & Woman & Man & \multirow[t]{2}{*}{ Woman (\%) } & \multirow{2}{*}{$\begin{array}{l}\text { Man } \\
(\%)\end{array}$} & \multirow{2}{*}{$\begin{array}{l}\text { General } \\
(\%)\end{array}$} \\
\hline & $\mathrm{n}$ & $\mathrm{n}$ & & & \\
\hline \multicolumn{6}{|c|}{$\begin{array}{c}\text { If your honey is candied in the refrigerator, is it real honey? } \\
\text { Buzdolabında bal şekerleniyorsa gerçek bal mıdır? }\end{array}$} \\
\hline Yes & 27 & 28 & 50 & 54.90 & 52.38 \\
\hline No & 27 & 23 & 50 & 45.09 & 47.61 \\
\hline \multicolumn{6}{|c|}{$\begin{array}{l}\text { Is intermittently flowing honey fake? } \\
\text { Kesik kesik akan bal sahtemidir? }\end{array}$} \\
\hline Yes & 34 & 42 & 62.96 & 82.35 & 72.38 \\
\hline No & 20 & 9 & 37.03 & 17.64 & 27.65 \\
\hline \multicolumn{6}{|c|}{$\begin{array}{l}\text { Is honey that does not freeze in cold weather fake? } \\
\text { Soğuk havada donmayan bal sahte midir? }\end{array}$} \\
\hline Yes & 29 & 33 & 53.70 & 64.70 & 59.04 \\
\hline No & 25 & 18 & 46.29 & 35.29 & 40.95 \\
\hline
\end{tabular}

It was determined that $53.71 \%$ of the " yes and no" answers, which is another question about real honey, given whether the honey that does not freeze in cold weather is fake or not, consists of women and $64.70 \%$ of them are men. It was reported that most of the participants (59.04\%) thought that honey freezing in cold weather was real. According to the results of the survey, it is concluded that in parallel with the consumption of honey, people have the characteristics of distinguishing between real and fake honey.

Table 20. Consumers' Honey Therapeutic Use Status by Gender

Çizelge 20. Cinsiyete Göre Tüketicilerin Balı Tedavi Amaçlı Kullanım Durumu

\begin{tabular}{lccccc}
\hline & Woman & Man & & Man & \multicolumn{2}{c}{$\begin{array}{c}\text { General } \\
\text { Options }\end{array}$} & $\mathrm{n}$ & $\mathrm{n}$ & Woman $(\%)$ & $(\%)$ & \\
\cline { 2 - 5 } I use it sometimes & 32 & 29 & 59.25 & 56.86 & 58.09 \\
\hline I've never used & 3 & 4 & 5.55 & 7.84 & 6.66 \\
\hline I always use honey & 19 & 18 & 35.18 & 35.29 & 35.23 \\
\hline
\end{tabular}


In general, it is observed that the participants sometimes or always use honey for therapeutic purposes. The rate of those who never used honey in diseases was found to be $6.66 \%$. According to the results of the survey, it is observed that people have knowledge that honey can be used for therapeutic purposes due to its antimicrobial activity, while considering the proportion of those who never use honey, people should be more conscious about the therapeutic properties of honey.

\subsection{The importance of honey for health}

In the survey made to customers coming to different businesses in Erzurum, different questions were asked about the importance of honey in terms of health. These questions are that honey expels toxic substances from the body, heals wounds, is good for insomnia and heart palpitations, is used in the treatment of ulcers and liver diseases. Answers were recorded as "yes or no". As a result of the analysis of variance, the difference of their responses was found to be statistically insignificant, while the answers of the consumers regarding the use of honey for heart palpitations, ulcers and the treatment of liver diseases were found to be statistically significant $(\mathrm{p}<0.05)($ Table 20). Arvaitoyannis and Krystallis, 2006, in their research findings, reported that honey consumed for skin, anti-aging, anti-cancer, and health. Kumova and Korkmaz 2000 reported that honey was used in diseases such as Pharyngitis, Ulcer, Gastritis, Common Cold, Angina, Diabetes, Asthma, Bronchitis, Cancer. The research results have been determined to be consistent with our findings.

Table 21. Chi-square Test Result Showing the Health Importance of Honey Between the Genders

Çizelge 21. Cinsiyetler Arasında Balın Sağlık Açısından Önemini Gösteren Ki-kare Test Sonucu

\begin{tabular}{|c|c|c|c|}
\hline Options & Df & $\mathrm{X}^{2}$ & $\begin{array}{l}\text { Importance } \\
\text { level }\end{array}$ \\
\hline $\begin{array}{lr}\text { Expelling } & \text { toxic } \\
\text { substances from the } \\
\text { body }\end{array}$ & 1 & 0.99 & ns \\
\hline Heart palpitations & 1 & 0.54 & $*$ \\
\hline Insomnia & 1 & 1.06 & $*$ \\
\hline To facilitate digestion & 1 & 1.88 & ns \\
\hline Ulcer & 1 & 0.48 & $\mathrm{~ns}$ \\
\hline Heal wounds & 1 & 0.13 & ns \\
\hline Liver diseases & 1 & 1.72 & $*$ \\
\hline
\end{tabular}

While $62.96 \%$ of the women among the consumers who participated in the survey thought that honey is good for heart palpitations, this rate was recorded as $82.35 \%$ for men. Most of the participants $(89.52 \%)$ agreed that honey has therapeutic properties in ulcer disease and $86.66 \%$ of them can be used in liver diseases (Table 21).

It has been observed that the benefits of honey, which is a source of healing for humans due to its vitamins and minerals and its structural properties, are not fully known by consumers. For this purpose, people need to be more aware of the benefits of honey.

\section{Conclusion}

In the survey study, a questionnaire containing questions about honey marketing problems in Erzurum market and the honey consumption habits of people was applied and the following results were obtained. It has been determined that most of the consumers have a habit of consuming honey and they always try to use honey in their daily diet. In honey consumption, the quality, taste and source of honey are of great importance for consumers. It has been determined that the consumers do not take the color of honey into consideration when perceiving the quality of honey. In the survey study, it was determined that the effect of the brand on the honey purchasing behavior and consumption habits of the consumers is not important. Today, considering the functions of the brand to inform and protect consumers, to create customer satisfaction and customer loyalty, this result reflects a negative situation in terms of honey production and marketing. For this reason, marketing strategies that give importance to quality and brand should be generalized in Erzurum region. For consumers, the date when honey was produced has been very important in terms of preserving the nutritional properties of honey. Consumers, who prefer more filtered honey, think that honey prices are normal. In our country, there were not enough studies on the subjects discussed in this study, and the findings obtained from the survey study could not be compared with the literature in the thesis, since the topographic structure, climate, vegetation, eating habits and different consumption habits of the people differ in the studies conducted abroad. As a result of It has been observed that the benefits of honey, which is a source of healing for humans due to its vitamins and minerals and its structural properties, are not fully known by consumers. For this purpose, people need to be more aware of the benefits of honey. 
Table 22. The Therapeutic Use of Honey in Various Diseases

Çizelge 22. Balın Çeşitli Hastalıklarda Tedavi Amaçlı Kullanılması

\begin{tabular}{|c|c|c|c|c|c|}
\hline \multirow[b]{2}{*}{ Options } & Woman & Man & \multirow[t]{2}{*}{ Woman (\%) } & \multirow{2}{*}{$\begin{array}{l}\text { Man } \\
(\%)\end{array}$} & \multirow{2}{*}{$\begin{array}{l}\text { General } \\
(\%)\end{array}$} \\
\hline & $\mathrm{n}$ & $\mathrm{n}$ & & & \\
\hline \multicolumn{6}{|c|}{$\begin{array}{l}\text { It throws out toxic substances from the body } \\
\text { Vücuttaki zehirli maddeleri dişarı atar }\end{array}$} \\
\hline Yes & 27 & 28 & 50 & 54.90 & 52.38 \\
\hline No & 27 & 23 & 50 & 45.09 & 47.61 \\
\hline \multicolumn{6}{|c|}{$\begin{array}{l}\text { Good for heart palpitations } \\
\text { Kalp çarpıntısına iyi gelir }\end{array}$} \\
\hline Yes & 34 & 42 & 62.96 & 82.35 & 72.38 \\
\hline No & 20 & 9 & 37.03 & 17.64 & 27.65 \\
\hline \multicolumn{6}{|c|}{$\begin{array}{l}\text { Good for insomnia } \\
\text { Uykusuzluğa iyi gelir }\end{array}$} \\
\hline Yes & 29 & 33 & 53.70 & 64.70 & 59.04 \\
\hline No & 25 & 18 & 46.29 & 35.29 & 40.95 \\
\hline \multicolumn{6}{|c|}{$\begin{array}{l}\text { It facilitates digestion } \\
\text { Hazmı kolaylaştırır }\end{array}$} \\
\hline Yes & 45 & 47 & 83.33 & 92.15 & 87.61 \\
\hline No & 9 & 4 & 16.66 & 7.84 & 12.38 \\
\hline \multicolumn{6}{|c|}{$\begin{array}{l}\text { Used in ulcer treatment } \\
\text { Ülser tedavisinde kullanilır }\end{array}$} \\
\hline Yes & 48 & 46 & 88.88 & 90.19 & 89.52 \\
\hline No & 6 & 5 & 11.11 & 9.80 & 10.47 \\
\hline \multicolumn{6}{|c|}{$\begin{array}{l}\text { Has the ability to heal wounds in the body } \\
\text { Vücuttaki yaraları iyileştirme özelliğine sahiptir }\end{array}$} \\
\hline Yes & 47 & 44 & 87.03 & 86.27 & 86.66 \\
\hline No & 7 & 7 & 12.96 & 13.72 & 13.33 \\
\hline \multicolumn{6}{|c|}{$\begin{array}{c}\text { Used in liver diseases } \\
\text { Karaciğer hastalıklarında kullanılır }\end{array}$} \\
\hline Yes & 42 & 42 & 77.77 & 82.35 & 80 \\
\hline No & 12 & 9 & 22.22 & 17.64 & 20 \\
\hline
\end{tabular}

Acknowledgments: Bu tez çalışmamda katkılarından dolayı Prof. Dr. Ferat GENÇ ve Doç. Dr. Berna EMSEN STAINMAN' teşekkür ederim.

\section{References}

Anonim, 2004. T.C Tarım ve Köy İşleri Bakanlığı. II. Tarım Şurası, Hayvan, Su Ürünleri Yetiştiriciliği ve Sağlı̆̆ı, Ankara, 35-42 s.

Anonim, 2019. Türkiye İstatistik Kurumu, Hayvancilik İstatistikleri, http://www.tuik.gov.tr/hayvancilikapp/hayvancilik.zul (19.03.2021).

Arvanitoyannis, I., Krystallis, K., 2006, An empirical examination of the determinants of honey consumption in Romania, International Journal of Food Science and Technology, p; 164-1176.

Baki, F., Saner, G., Adanacioğlu, H., Güler, D., 2017, IV. IBANESS Congress Series - Russe / Bulgaria, Kongresi bildiriler kitab1, s.785. Bulgaristan.

FAO, 2018. Statistical Databases/Agriculture, FAOSTAT, www.fao.org (19/03/2021).

Fıratlı, Ç., Gençer H.V., 1994. Dünya arııllı̆̆ ve Türkiye'nin yeri, Türkiye II. Tek. Arıcılık Kong. (8-9 Şubat 1994), Ankara. 
Fıratlı, Ç., Genç F., Karacaoğlu M., Gençer H.V. 2000. "Türkiye Arıcılığının Karşılaştırmalı Analizi Sorunlar Öneriler” TMMOB Ziraat Mühendisleri Odası, Türkiye Ziraat Mühendisleri Birliği. V. Teknik Kongresi, 811-826 s.

Kaftanoğlu, O., Kumova U., Yeninar, H., 1992. Varroa mücadelesinde son gelişmeler. Doğu Anadolu Bölgesi I. Arıcılık Semineri, 127-137 s, Erzurum.

Kumova, U., Korkmaz, A., 2000. Arı Ürünleri Tüketim Davranışları Üzerine Bir Araştırma. Türkiye'de Arıcılık Sorunları ve I. Ulusal Arıcılık Sempozyumu. 28-30 Eylül 1999. Kemaliye/Erzincan.

Kumova, U., 2001. Varroa jacobsoni kontrolünde ülkemizde kullanılan bazı ilaçların etkinliğinin araştırılması. Türk. J. Vet. Anim. Sci., 25:597-602.

Roman, A., Pleban, E,P., Kozak, M., 2013, Factors Influencıng Consumer Behavior Relatıng To The Purchasıng Of Honey Part 1. The Buying Process And The Level Of Consumption, DOI: 10.2478/jas-2013-0026J. APIC. SCI. Vol. 57 No. 2

Saner, G., Yücel, B., Yercan, M., Karaturhan, B., Engindeniz, S., Çukur, F., Kösoğlu, M., 2011. “Organik ve Konvansiyonel Bal Üretiminin Teknik Ve Ekonomik Yönden Geliştirilmesi Ve Alternatif Pazar Olanaklarının Saptanması Üzerine Bir Araştırma: İzmir İli Kemalpaşa ilçesi Örneği, Gıda tarım ve Hayvancılık Bakanlığı Tarımsal Ekonomi ve Politika Geliştirme Enstitüsü (TEPGE) Yayınları, Yayın No: 195, Ankara.

Sayılı, M., 2013. Tokat İlinde Tüketicilerin Arı Ürünleri Tüketim Durumları ve Alışkanlıkları. Uludağ Arıcılık Dergisi, 13 (1): 16-22, Bursa.

Yıldız, N., Bircan H., 1994. Araştırma ve Deneme Metotları. Atatürk Üniversitesi, 266 s, Erzurum. 